UCRL-ID-119210

\title{
Genesis Eco Systems, Inc. Soil Washing Process
}

\author{
Robert J. Cena
}

October 11, 1994

This is an informal report intended primarily for internal or limited external distribution. The opinions and conclusions stated are those of the author and may or may not be those of the Laboratory.

Work performed under the ausplces of the U.S. Department of Energy by the Launence Livermore National Laboratory under Contract W-7405-Eng-48.

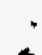

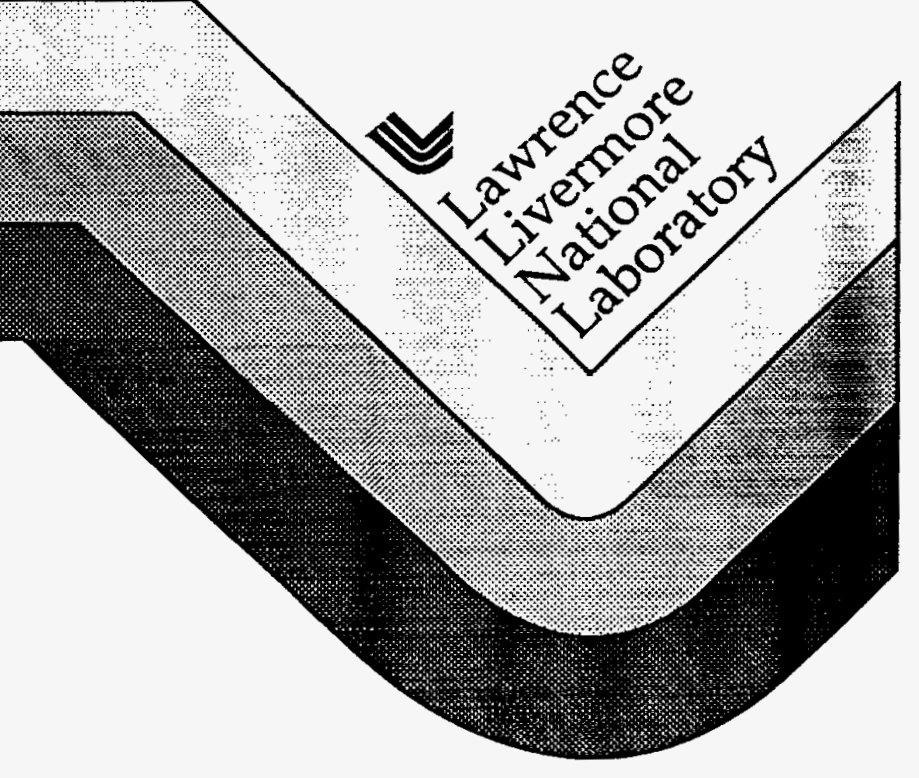




\section{DISCLAIMER}

This document was prepared as an acccount of work sponsored by an agency of the United States Government. Neither the United States Government nor the University of California nor any of their employees, makes any warranty, express or implied, or assumes any legal liability or responsibility for the accuracy, completeness, or usefulness of any information, apparatus, product, or process disclosed, or represents that its use would not infringe privately own rights. Reference herein to any specific commercial products, process, or service by trade name, trademark, manufacturer, or otherwise, does not necessarily constitute or imply its endorsement, recommendation, or favoring by the United States Government or the University of California. The views and opinions of authors expressed herein do not necessarily state or reflect those of the United States Government or the University of California, and shall not be used for advertising or product endorsement purposes.

This report has been reproduced directly from the best available copy.

Available to DOE and DOE contractors from the Office of Scientific and Technical Information P.O. Box 62, Oak Ridge, TN 37831

Prices available from (615) 576-8401, FTS 626-8401

Available to the public from the National Technical Information Service

U.S. Department of Commerce 5285 Port Royal Rd. Springfield, VA 22161 


\section{DISCLAIMER}

Portions of this document may be illegible in electronic image products. Images are produced from the best available original document. 
Genesis Eco Systems, Inc Soil Washing Process

Genesis Eco Systems' (Genesis) soil washing process was evaluated as part of the Lawrence Livermore National Laboratories (LLNL) small business technology transfer technical assistance initiative. Under this initiative, case number 93131, an LLNL technical contact evaluated the operation and effectiveness of the Genesis soil washing system for the remediation of hydrocarbon contaminated soil. The process demonstration occurred at a former McDonnell Douglas Aerospace facility in Rancho Cordova, California. The report presents the following information:

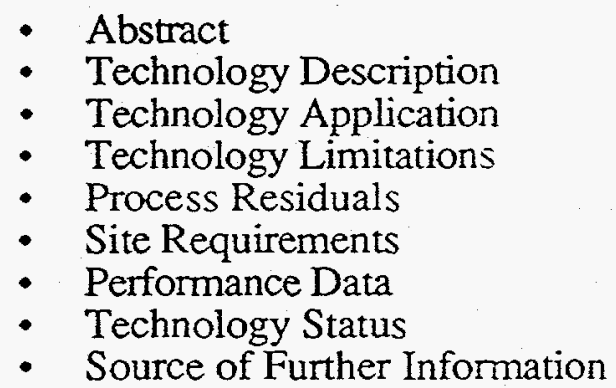

\section{Abstract}

The Genesis soil washing system is an integrated system of modular design allowing for maximum material handling capabilities, with optimized use of space for site mobility. The $\underline{S}$ urfactant $\underline{A}$ ctivated $\underline{B}$ io-enhanced $\mathbf{R}$ emediation $\underline{E}$ quipment-Generation $\underline{I}$ (SABRE-1, Patent Applied For) modification was developed specifically for removing petroleum byproducts from contaminated soils. Scientifically formulated surfactants, introduced by high pressure spray nozzles, displace the contaminant from the surface of the soil particles into the process solution. Once the contaminant is dispersed into the liquid fraction of the process, it is either mechanically removed, chemically oxidized, or biologically oxidized. The contaminated process water is pumped through the Genesis Biosep (Patent Applied For) filtration system where the fines portion is flocculated, and the contaminant-rich liquid portion is combined with an activated mixture of nutrients and carefully selected bacteria to decompose the hydrocarbon fraction. The treated soil and dewatered fines are transferred to a bermed stockpile where bioremediation continues during drying. The process water is reclaimed, filtered, and recycled within the system.

LLNL has evaluated the SABRE process as part of the LLNL small business technology transfer technical assistance initiative. The process was evaluated at a former McDonnell Douglas Aerospace facility. The project involved the remediation of 4,590 short tons of soil contaminated with an average of 3,031 parts per million (ppm) fuel oil. The soil washing process was carried out over a period of 33 operating days, which included mobilization, setup, testing, cleanup, and demobilization. Immediately after washing, the average contaminant level was reduced by 98 to 99 percent, to $41 \mathrm{ppm}$. After being allowed to sit for one week, contaminant reductions of an additional 40 to 100 percent were noted. At the end of the project, the residual water in the SABRE system was analyzed and found to be completely free of diesel contamination due to the enhanced microbial activity of the system. LLNL performed an analysis of the project and evaluated it on seven criteria established by the Environmental Protection Agency (EPA) for the Superfund Feasibility Study (FS) process. Results of the evaluation are summarized in Table 1. 
Table 1. Criteria Evaluation for the Genesis SABRE process.

\begin{tabular}{|c|c|c|c|c|c|c|}
\hline $\begin{array}{l}\text { Overall } \\
\text { Protection } \\
\text { of Human } \\
\text { Health and } \\
\text { the } \\
\text { Environment }\end{array}$ & $\begin{array}{l}\text { Compliance } \\
\text { with } \\
\text { Federal } \\
\text { ARARs }(1)\end{array}$ & $\begin{array}{l}\text { Long-term } \\
\text { Effectiveness } \\
\text { and } \\
\text { Performance }\end{array}$ & $\begin{array}{l}\text { Reduction of } \\
\text { Toxicity, } \\
\text { Mobility, or } \\
\text { Volume } \\
\text { Through } \\
\text { Treatment }\end{array}$ & $\begin{array}{l}\text { Short-term } \\
\text { Effective- } \\
\text { ness }\end{array}$ & $\begin{array}{l}\text { Ease with } \\
\text { which the } \\
\text { Process } \\
\text { can be } \\
\text { Implemen } \\
\text { ted }\end{array}$ & Cost \\
\hline $\begin{array}{l}\text { Provides both } \\
\text { short- and long- } \\
\text { term protection. }\end{array}$ & $\begin{array}{l}\text { Requires } \\
\text { compliance } \\
\text { with } \\
\mathrm{RCRA}^{(2)} \\
\mathrm{TSDF}(3) \\
\text { regulations if } \\
\text { the material is } \\
\text { a hazardous } \\
\text { waste. }\end{array}$ & $\begin{array}{l}\text { Effecively } \\
\text { removes } \\
\text { contamination } \\
\text { source. }\end{array}$ & $\begin{array}{l}\text { Reduces or } \\
\text { eliminates } \\
\text { toxicity, } \\
\text { mobility, and } \\
\text { volume of soil } \\
\text { contaminants } \\
\text { through } \\
\text { treatment. }\end{array}$ & $\begin{array}{l}\text { Contaminant } \\
\text { reduction is } \\
\text { immediate and } \\
\text { on-going. }\end{array}$ & $\begin{array}{l}\text { Involves } \\
\text { relatively } \\
\text { few } \\
\text { administra- } \\
\text { tive and } \\
\text { regulatory } \\
\text { difficulties. }\end{array}$ & $\begin{array}{l}\$ 30- \\
\$ 40 \\
\text { per } \\
\text { ton }(4)\end{array}$ \\
\hline $\begin{array}{l}\text { Prevents further } \\
\text { groundwater } \\
\text { contamination } \\
\text { and off-site } \\
\text { migration. }\end{array}$ & $\begin{array}{l}\text { Excavation, } \\
\text { construction, } \\
\text { and operation } \\
\text { of on-site } \\
\text { treatment unit } \\
\text { may require } \\
\text { compliance } \\
\text { with location } \\
\text { specific } \\
\text { ARARs. }\end{array}$ & $\begin{array}{l}\text { Involves well } \\
\text { demonstrated } \\
\text { technique for the } \\
\text { removal of } \\
\text { contaminants }\end{array}$ & & $\begin{array}{l}\text { May present } \\
\text { potential } \\
\text { short-term } \\
\text { risks to } \\
\text { workers and } \\
\text { community } \\
\text { from air } \\
\text { release during } \\
\text { excavation and } \\
\text { handling. }\end{array}$ & $\begin{array}{l}\text { Modular } \\
\text { nature } \\
\text { provides for } \\
\text { ease of set- } \\
\text { up and } \\
\text { flexibility } \\
\text { of } \\
\text { operation. }\end{array}$ & \\
\hline $\begin{array}{l}\text { May require } \\
\text { measures to } \\
\text { protect workers } \\
\text { and community } \\
\text { during } \\
\text { excavation and } \\
\text { handling. }\end{array}$ & $\begin{array}{l}\text { System has } \\
\text { provisions for } \\
\text { emissions } \\
\text { controls to } \\
\text { ensure } \\
\text { comliance } \\
\text { with air } \\
\text { quality } \\
\text { standards. }\end{array}$ & $\begin{array}{l}\text { No residuals } \\
\text { requiring } \\
\text { treatment after } \\
\text { project } \\
\text { completion. }\end{array}$ & . & & & \\
\hline
\end{tabular}

(1) Applicable or Relevant and Appropriate Requirements

(2) Resource Conservation and Recovery Act

(3) Transportation, Storage, and Disposal Facility

(4) Actual remediation costs are site and project specific. Factors which effect costs include mobilization/demomilization costs, the volume of soil to be remediated, type and levels of contamination, soil type, and target cleanup levels. Cost data presented in this table are average costs to treat a minimum of 500 tons of soil. 


\section{Technology Description}

The SABRE-1 Soil Washing System is a system specifically designed for the remediation of hydrocarbon contaminated soil. The system breaks apart the soil and . utilizes a combination of surfactant stripping and active bioremediation to degrade contamination. The equipment removes contamination by utilizing a proprietary surfactant blend that is non-toxic to personnel, wildlife, or aquatic life, and is $100 \%$ biodegradable.

The SABRE-1 Soil Washing System is a fully mobile system that includes two 40foot trailer-mounted modules and a $6 \times 12$ foot skid-mounted module. The basic system modules are the actual soil washer, the Biosep filtration and fines separation module, and a chemical handling system. Primary power for the system comes either from a generator mounted on the washer module or from external line current. The system is operated by a crew of four, including a project supervisor/system operator, two materials handlers, and a laborer. For most projects the only support equipment required are two loaders to load the soil washer and to transport washed soil to the clean soil stockpile. The SABRE-1 system requires a working area of approximately 50 feet by 80 feet for the remediation process.

The remediation process involves excavation of the contaminated material on the site and stockpiling. Ideally, the material to be cleaned is stockpiled in 50 cubic yard lots. The contaminated soil is loaded onto a conveyor which transports the soil into the soil washing unit for cleaning. During the wash process the soil is broken up and mixed with the wash solution, the contamination segregates out into the wash solution and the washed soil passes through a dewatering system. Following cleaning, the cleaned soil is dewatered and stockpiled for reuse. Following treatment of the contaminated soil, the wash solution containing the contamination and cleaning agents is recycled within the system. Within the Biosep filtration module, the hydrocarbons are removed from the water by a highly accelerated bioremediation process, fines are removed from the water through a fines handling system, and the process water containing the cleaning agent is reused. All cleaning and stockpiling of soil is conducted in bermed areas on an impermeable substrate to prevent the accidental spread of any contamination. Waste waters which remain at the end of the soil washing process are quickly and easily bioremediated on site at the end of the project.

Genesis cleaning solutions are formulated based on the latest developments in environmentally friendly cleaners. These cleaning solutions contain no solvents or heavy metals, and are non-toxic and biodegradable. The cleaning solutions contain a complex mixture of surfactants which separate contamination from the soil and act to accelerate biodegradation rates of any contaminants remaining in the soil. Cleaning of soils is primarily by "roll-up" and emulsification of contamination. Roll-up occurs where the surfactant displaces the contamination from the soil substrate in an aqueous media. Roll-up does not occur in all detergency situations involving oily contaminants. If the surfactant is incapable of displacing the contamination from the substrate, it can cause the contamination to spread over the substrate in a thin film. Removal of the contaminant from the substrate will then occur by emulsification.

The Genesis Soil Washing System is capable of cleaning most types of hydrocarbon contamination including gasoline, diesel, motor oil, and fuel oil. The system handles most soil types including clays, and can handle contaminant levels in excess of $50,000 \mathrm{ppm}$. A single wash is capable of reducing contaminant levels by $95 \%$ to $99 \%$, and higher levels are attainable with multiple washes. Typical wash rates with the SABRE-1 system are 25 to 35 short tons per hour or about 200 short tons per 8 hour wash day. Figure 1 is a Schematic diagram of the SABRE system for the remediation of hydrocarbons. 


\section{Genesis Eco-System, Inc. SABRE ${ }^{\mathrm{tm}}$ Soil Washing Technology}

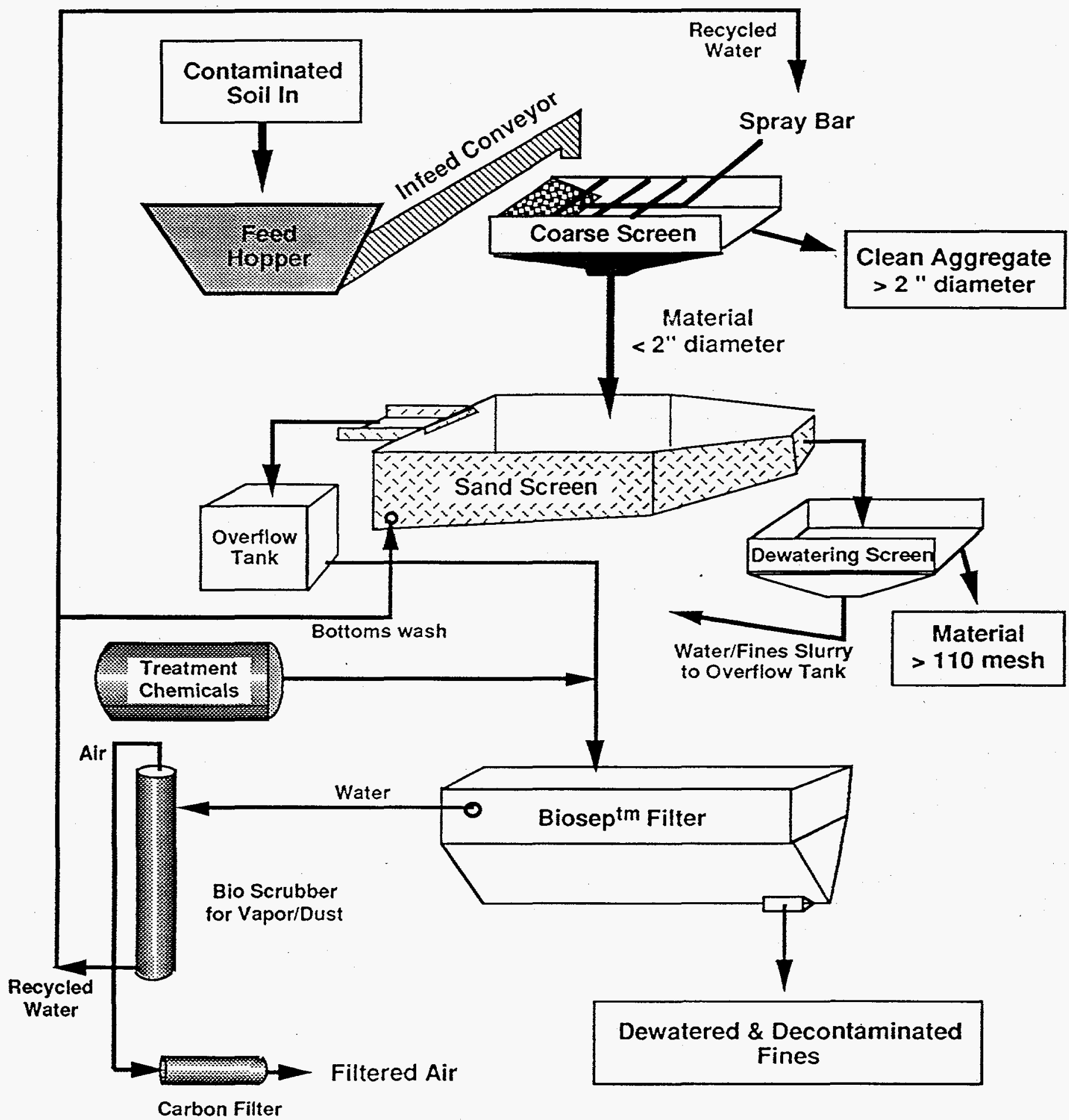

Figure 1. Process Diagram - Gensis Eco Systems Inc. SABRE ${ }^{\mathrm{tm}}$ Soil Washing System 


\section{Technology Application}

The Genesis SABRE technology is a stand alone technology incorporating bioremediation, which actively reduces residual contaminant levels even after initial treatment. The system can process soils containing more than 60 percent sand and other coarse material at the rate of 25 to 40 short tons per hour. In order to evaluate its fines handling ability, the system was tested using 180 tons of soil containing over 40 percent material less than 200 mesh. The system successfully washed the soil with a high percentage of fines at the rate of 16 to 25 short tons per hour. During the treatment process, clasts larger than seven inches are screened from the soil as it is loaded into the feed hopper.

The SABRE process is designed to extract petroleum hydrocarbons including gasoline, kerosene, jet fuel, diesel fuel, fuel oil, and motor oil from soils. The technology should also be adaptable to the remediation of soils contaminated with volatile and nonvolatile hydrocarbons, chlorinated hydrocarbons, pesticides, polycyclic aromatic hydrocarbons, PCBs, and some metals. The Genesis SABRE-1 process was evaluated during the remediation of a leaking underground storage tank (LUST) site at a former McDonnell Douglas Aerospace facility in Rancho Cordova, California.

\section{Technology Limitations}

Traditional soil washing technologies act to concentrate contamination to reduce overall volume. The decrease in volume does nothing to decrease contaminant mass, and actually increases relative toxicity. Since the SABRE process uses biodegradation to enhance the process, actual contaminant mass and thus relative toxicity are reduced along with contaminant volume.

Soil washing technologies in the past have met with limited success in remediating material with normal to high percentages of fines. The lack of success has been a result of both chemical and mechanical factors. Contaminants typically adsorb directly onto the surface of the soil particles. Most frequently, contaminants concentrate in the fines fraction (i.e. silts and clays) because of the higher surface to bulk ratio. Fine particles tend to stay entrained in typical wash solutions, due to the suspensive nature of most surfactants, and present a fluid/material handling problem. Genesis' SABRE process was successfully demonstrated in soils with about 30 percent silt and clay sized material. Genesis reported that they had successfully tested the system on soils with over 40 percent fines smaller than 200 mesh. The Genesis SABRE process uses tailored surfactants and polymers which work sympathetically with the Biosep filter to enhance fines separation and displacement of contaminant from the soil surface.

\section{Process Residuals}

The SABRE process generates only one quantifiable waste stream, treated solids. A second waste stream, spent carbon from the final stage of a scrubber system currently being installed to control air emissions, may potentially be identified.

After washing and biodegradation, treated solids are recycled for use as fill or for a source of sand, aggregate, and top soil. In the case of the McDonnell Douglas project, the treated soil was reused on site to backfill the excavation from which they were removed. 
The water used in the SABRE process is recycled in the system and does not need disposal. During the treatment process, the Biosep filter acts as a large bioreactor. The fines portion and contaminant are removed as the water is recycled. The high level of bioactivity in the system degrades waterborne contaminants such that the process water at the end of a remedial project is non-detect for contamination. Generally, less than 6,000 gallons of process water remain at the end of the project, all of which can be used on site for agricultural water, dust control, or disposed of in a municipal sewer. At the time that this report was being prepared, plans and specifications were being prepared to fit the SABRE system with a scrubber to control all air emissions from the system, including those associated with its diesel power plant.

\section{Site Requirements}

The Genesis SABRE soil washing system includes three major modules: the wash unit, the Biosep filtration unit, and the chemical handling and injection unit. Actual system setup is accomplished in one to two days on most sites. The setup time includes preparation of the treatment pad and hooking up water and utilities. Daily maintenance during treatment takes an average of 30 to 60 minutes for lubrication, cleaning, and normal preventative checks. The average additional total time required for maintenance and repairs to the system is 1 hour for each 10 hours of operation. A typical project, washing 2,700 short tons of soil, requires approximately 14,000 square feet (one third acre) for equipment setup and operation, and the treated and untreated material stockpiles. The actual treatment unit is set up on a 30 foot by 50 foot pad. A 10 mil plastic barrier is placed under the SABRE system and the treatment area is surrounded by 6 inch berms to control soil and water runoff.

Soils requiring treatment can be taken directly from a contaminated excavation or from a contaminated soil stockpile. It is preferable that soils be stockpiled prior to treatment since excavation and treatment rates will likely vary. Stockpiling of excavated soil also allows for pretreatment sampling. Pretreatment sampling can reduce the soil volume requiring treatment by screening out material which already meets treatment standards. The pretreatment sampling also provides data for maximizing the wash process efficiency by tailoring it to soil type and contaminant characteristics.

Contaminated soil should be stockpiled on visqueen in a bermed area and covered or enclosed to prevent possible run-off, blowing dust, or the escape of volatile components into the atmosphere. For large or long term projects and soils with high concentrations of volatile components, the entire treatment area can be enclosed.

No dedicated utilities are required for the operation of the Genesis SABRE system. On those sites where water is not directly available, a portable water tank or water truck can be used. A maximum of 600 gallons per hour or 3,000 gallons of water per operating day are needed to wash 200 short tons of soil. The SABRE system can either run from a builtin generator or from line current. One 300-ampere, 240-volt three-phase electrical circuit will power the SABRE system. The use of line current, where practical, effectively reduces operating noise associated with the system. All powered systems on the unit are driven by electric motors or by hydraulic motors powered by an electro-hydraulic supply. The hydraulic fluid and most of the lubricants used in the system are vegetable based, and are non-toxic and 100 percent biodegradable.

\section{Performance Data}


The Genesis SABRE system was specifically designed to treat soil contaminated with petroleum hydrocarbons. The system's ability to treat fuel oil contaminated soil was viewed as a good test of its functionality. Fuel oil is essentially a heavy diesel fuel and contains a significant percentage of medium chain-length hydrocarbons and relatively few light components. Fuel oil also has a low vapor pressure. Consequently, any decrease in contaminant concentration during treatment could not be attributed to volatilization. About 4,950 short tons of fuel oil contaminated soil were successfully treated for the McDonnell Douglas project. Results of soil analysis did not reveal the presence of any other contaminants including volatile organic compounds (VOCs).

The Genesis SABRE technology was evaluated based on its ability to remediate petroleum contaminated soil. The evaluation objectives for the system were:

- determine how efficiently the system removes petroleum hydrocarbons from soils

- evaluate whether the SABRE system's performance is consistant and reproducible over a long term with constant operating conditions

- gather information necessary to estimate processing rates, determine process chemical dosages, evaluate support requirements, develop maintenance and repair schedules, and define treatment costs

- obtain information on biodegradation of residual hydrocarbons in the soil by monitoring contaminant levels in treated soil over a specific time period

During the course of the project, soil was washed and stockpiled in 50 cubic yard (c.y.) lots to satisfy regulatory requirements. Following the wash process, a composite sample was collected from each $50 \mathrm{c}$.y. lot, and analyzed for total petroleum hydrocarbons (TPH) as diesel fuel by EPA Method 8015 modified. Basic operational parameters were also monitored including soil grain size distribution (Table 2). The $\mathrm{pH}$ in the system was monitored throughout the project and remained constant at 6.8 to 7.0 . Based on analytical data collected during excavation, the average level of contamination in the soil needing remediation was $3,031 \mathrm{ppm}$ TPH-Diesel with maximum levels of $11,000 \mathrm{ppm}$ (Table 3 Pre-wash analytical data).

Soil washing operations were carried out over 33 actual washing days, including those days used for set-up and initial system testing. The maximum amount of soil washed in one 8 hour work day was 235 short tons. The limiting factor in the wash process was the ability of the equipment to handle fine material less than 200 mesh in size.

The contaminated soil was stockpiled on visqueen in a 60 foot X 140 foot enclosure, bermed with $\mathrm{K}$-rail. The stockpile and berm were also covered with visqueen to exclude water and assure zero discharge. Following treatment, the washed soil was stockpiled in 50 c.y. lots. Composite samples were collected from each stockpile and analyzed by EPA Method 8015 modified for diesel, to verify that cleanup objectives had been achieved. Lots of soil which did not initially meet cleanup goals were allowed to sit and then resampled in one week after which the material met or surpassed cleanup goals. All post wash analytical data is presented in Table 4 including data showing additional reductions in contaminant levels after washing.

Based on the pre-wash and post-wash analytical data, the soil washing process was able to immediately produce a near 100 fold reduction in contaminant levels with a single wash. The average level of diesel contamination in the soil was reduced from $3,031 \mathrm{ppm}$ to $43.1 \mathrm{ppm}$ after one pass through the system. After allowing the soil to sit for an average of one week after washing, additional reductions in contaminant levels ranging from 40 to 100 percent were observed. The apparent limiting factor in reducing contaminant levels to 
non-detect within one week was the availability of soil nutrients. This hypothesis was tested by taking a 50 c.y. lot of soil which, after washing, was $110 \mathrm{ppm}$, and adding additional soil nutrients. After one week, the soil was non-detect for fuel contamination. To overcome the nutrient limitation, a proprietary nutrient mixture was added to the system to enhance bioremediation. Based on the final samples, all of the contaminated soil treated by the Genesis Eco Systems SABRE-1 Soil Washing System had been successfully remediated to levels meeting or exceeding the regulatory cleanup levels set for this project. The remediated washed soil was reused on site as backfill.

An initial concern with the SABRE process was the possible build-up of hydrocarbon contamination in the process within the system. The concern over build-up proved to be unfounded. Some hydrocarbon float was noted on water in the soil washer tanks at the end of operating days. However, the high bioactivity within the system degraded the residual, and within 12 hours the float was degraded. At the completion of the soil washing process, the wash water was tested for diesel contamination and found to be non-detect due to the accelerated bioremediation occurring within the SABRE-1 system. The Sacramento County EMD allowed the non-contaminated process water to be used on site for dust control after all washing had been completed.

After totaling all costs and expenses, the cost to treat the soil at the McDonnell Douglas facility was calculated. Based on the information compiled during the project, the cost to treat 2,000 tons of soil at a comparable site is $\$ 33.75$ per ton. This cost can be expected to vary depending on mobilization and demobilization costs, contaminant type, contaminant level, and the volume and type of soil treated.

\section{Technology Status}

Genesis Eco Systems Inc. completed the washing of 4,590 short tons of fuel oil contaminated soil at a former McDonnell Douglas Aerospace facility. Samples were collected both before and after washing and analyzed for TPH-diesel. Pre-wash samples were collected by McDonnell Douglas' consultant and analyzed by an independent testing laboratory certified for such analysis by the California Environmental Protection Agency (Cal-EPA). Post wash samples were collected by a California Registered Geologist under legal chain-of-custody protocol, and analyzed by an independent testing laboratory certified for such analysis by the Cal-EPA. Contaminant levels in the unwashed soil ranged from $1,000 \mathrm{ppm}$ to $11,000 \mathrm{ppm}$ TPH-diesel and averaged 3,031 ppm. After washing, contaminant levels were reduced to levels ranging from 0 to $130 \mathrm{ppm}$ TPH-diesel, averaging $43.1 \mathrm{ppm}$. The average reduction in contaminant levels was 98.6 percent after a single wash. When the material was allowed to sit one week after washing, all of the washed soil passed treatment standards and additional contaminant reductions of 40 to 100 percent were noted.

The McDonnell Douglas project proved the SABRE system's capacity to handle and effectively treat the abundant fines portions (commonly $30 \%$ ) found in average soils. The system's effectiveness was also tested on a trial run of 181 short tons of very fine soil analyzed as $43 \%-200$ mesh, with a maximum size of \#4 mesh ( 0.187 inches), contaminated with an average of $700 \mathrm{ppm}$ oil and diesel. The SABRE system was able to successfully process this soil with a high percentage of fines at a rate of 25 tons per hour.

Genesis has recently completed modifications to the SABRE-1 system to enhance overall operating efficiencies. Genesis makes the SABRE system available to remediation contractors as a completely integrated package, including a thorough operator training program. The standard portable system is capable of washing 200 short tons of soil at 30 percent fines and 5,000 ppm diesel in an 8 hour working period. 
Table 2

Grain Size Distribution for Soils

Prior to Washing at the Former McDonnell Douglas Facility

Rancho Cordova, CA

\begin{tabular}{|c|c|c|c|c|c|c|}
\hline $\begin{array}{c}\text { Sieve } \\
\text { Size(U. S. } \\
\text { Standard) }\end{array}$ & $\begin{array}{c}\text { Particle } \\
\text { Diameter } \\
\text { Inches }\end{array}$ & $\begin{array}{c}\text { Particle } \\
\text { Diameter } \\
\text { Millimeters }\end{array}$ & $\begin{array}{c}\text { Weight } \\
\text { Retained } \\
\text { (grams) }\end{array}$ & $\begin{array}{c}\text { Accumulat } \\
\text { ed Wt. } \\
\text { Retained } \\
\text { (grams) }\end{array}$ & $\begin{array}{c}\text { Weight } \\
\text { Passing } \\
\text { (grams) }\end{array}$ & $\begin{array}{c}\text { Percent } \\
\text { Passing }\end{array}$ \\
\hline $3^{\prime \prime}$ & 3 & 76.2 & & - & & \\
\hline $1-1 / 2^{\prime \prime}$ & 1.5 & 38.1 & 0 & 0 & $3,956.2$ & 100 \\
\hline $3 / 4^{\prime \prime}$ & 0.75 & 19 & 604.1 & 604.1 & $3,352.1$ & 84.7 \\
\hline $1 / 2^{\prime \prime}$ & 0.5 & 12.5 & 377.9 & 982 & $2,974.2$ & 75.2 \\
\hline $3 / 8^{\prime \prime}$ & 0.375 & 9.5 & 164.6 & $1,146.6$ & $2,809.6$ & 71 \\
\hline$\# 4$ & 0.187 & 4.75 & 105.7 & $1,252.3$ & $2,703.9$ & 68.4 \\
\hline$\# 8$ & 0.094 & 2.36 & 144.7 & 1,397 & $2,559.2$ & 64.7 \\
\hline$\# 16$ & 0.0469 & 1.18 & 298.6 & $1,695.6$ & $2,260.6$ & 57.1 \\
\hline$\# 30$ & 0.0234 & 0.6 & 311 & $2,006.6$ & $1,949.6$ & 49.3 \\
\hline$\# 50$ & 0.0117 & 0.3 & 356.8 & $2,363.4$ & $1,592.8$ & 40.3 \\
\hline$\# 100$ & 0.0059 & 0.15 & 236.4 & $2,599.8$ & $1,356.4$ & 34.3 \\
\hline$\# 200$ & 0.0029 & 0.075 & 203.3 & $2,803.1$ & $1,153.1$ & 29.1 \\
\hline Pan & & & 8 & $2,811.1$ & $1,145.1$ & \\
\hline
\end{tabular}

Sample Description: Sandy Gravely Silt (GM), Yellowish Red, Unsorted, Rounded, Abundant Clay, Abundant Cobbles

Weight of Dry Soil Sample: 3956.2 grams 
Table 3

Pre-wash Analytical Results for Contaminated Material in the Pre-wash Stockpile at the Former McDonnell Douglas Facility

\begin{tabular}{|c|c|c|c|c|}
\hline $\begin{array}{c}\text { Sample } \\
\text { Number }\end{array}$ & $\begin{array}{c}\text { Date } \\
\text { Sampled }\end{array}$ & Media & Sample Type & $\begin{array}{c}\text { TPH-Diesel } \\
\text { TTLC (ppm) }\end{array}$ \\
\hline EX001 & $3 / 9 / 94$ & Soil & Grab & 2,300 \\
\hline EX002 & $3 / 10 / 94$ & Soil & Grab & 3,000 \\
\hline EX004 & $3 / 10 / 94$ & Soil & Grab & 3,000 \\
\hline EX005 & $3 / 10 / 94$ & Soil & Grab & 4,900 \\
\hline EX006 & $3 / 10 / 94$ & Soil & Grab & 1,100 \\
\hline EX007 & $3 / 10 / 94$ & Soil & Grab & 2,700 \\
\hline EX008 & $3 / 10 / 94$ & Soil & Grab & 4,100 \\
\hline EX009 & $3 / 10 / 94$ & Soil & Grab & 3,400 \\
\hline EX011 & $3 / 11 / 94$ & Soil & Grab & 2,200 \\
\hline EX013 & $3 / 11 / 94$ & Soil & Grab & 1,300 \\
\hline EX016 & $3 / 11 / 94$ & Soil & Grab & 1,400 \\
\hline EX018 & $3 / 15 / 94$ & Soil & Grab & 1,200 \\
\hline EX022 & $3 / 15 / 94$ & Soil & Grab & 3,100 \\
\hline EX027 & $3 / 16 / 94$ & Soil & Grab & 4,100 \\
\hline EX031 & $3 / 17 / 94$ & Soil & Grab & 2,400 \\
\hline EX032 & $3 / 17 / 94$ & Soil & Grab & 7,800 \\
\hline EX033 & $3 / 17 / 94$ & Soil & Grab & 11,000 \\
\hline EX035 & $3 / 17 / 94$ & Soil & Grab & 3,800 \\
\hline EX036 & $3 / 17 / 94$ & Soil & Grab & 1,900 \\
\hline EX037 & $3 / 17 / 94$ & Soil & Grab & 2,300 \\
\hline EX040 & $3 / 17 / 94$ & Soil & Grab & 1,200 \\
\hline EX041 & $3 / 17 / 94$ & Soil & Grab & 1,300 \\
\hline EX044 & $3 / 17 / 94$ & Soil & Grab & 1,200 \\
\hline
\end{tabular}

Note: Results are only presented for samples from soil actually placed in wash stockpile. 
Table 4

Sample Results from Washed Soil at the Former

McDonnell Douglas Aerospace Facility, Rancho Cordova, California

\begin{tabular}{|c|c|c|c|c|}
\hline $\begin{array}{l}\text { Sample } \\
\text { Number }\end{array}$ & Date Sampled & $\begin{array}{c}\text { TPH-Diesel } \\
\text { TTLC (STLC) } \\
(\mathrm{ppm})\end{array}$ & $\begin{array}{c}\text { Date } \\
\text { Resampled }\end{array}$ & $\begin{array}{l}\text { TPH-Diesel } \\
\text { TTLC (ppm) }\end{array}$ \\
\hline $525-1(\mathrm{~A}-\mathrm{D})$ & $5 / 25 / 94$ & $24(8.7)$ & n.a. & n.a. \\
\hline $\begin{array}{c}525-2 \\
\text { (See note } 1)\end{array}$ & $5 / 25 / 94$ & 16 & n.a. & n.a. \\
\hline $603-1(\mathrm{~A}-\mathrm{D})$ & $6 / 3 / 94$ & $4.9(1.3)$ & n.a. & n.a. \\
\hline $603-2(A-D)$ & $6 / 3 / 94$ & ND & n.a. & n.a. \\
\hline $603-3(A-D)$ & $6 / 3 / 94$ & $\overline{N D}$ & n.a. & n.a. \\
\hline $603-4(\mathrm{~A}-\mathrm{D})$ & $6 / 3 / 94$ & $\overline{\mathrm{ND}}$ & n.a. & n.a. \\
\hline $621-1(A-D)$ & $6 / 21 / 94$ & $17(1.9)$ & n.a. & n.a. \\
\hline $621-2(A-D)$ & $6 / 21 / 94$ & $21(2.4)$ & n.a. & n.a. \\
\hline $621-3(A-D)$ & $6 / 21 / 94$ & $30(2.4)$ & n.a. & n.a. \\
\hline $621-4(A-D)$ & $6 / 21 / 94$ & $26(2.5)$ & n.a. & n.a. \\
\hline $628-1(A-D)$ & $6 / 28 / 94$ & 31 & n.a. & n.a. \\
\hline $628-2(A-D)$ & $6 / 28 / 94$ & 23 & n.a. & n.a. \\
\hline $628-3(A-D)$ & $6 / 28 / 94$ & 20 & n.a. & n.a. \\
\hline $628-4(\mathrm{~A}-\mathrm{D})$ & $6 / 28 / 94$ & 13 & n.a. & n.a. \\
\hline $628-5(A-D)$ & $6 / 28 / 94$ & 14 & n.a. & n.a. \\
\hline $628-6(A-D)$ & $6 / 28 / 94$ & 16 & n.a. & n.a. \\
\hline $628-7(\mathrm{~A}-\mathrm{D})$ & $6 / 28 / 94$ & 10 & n.a. & n.a. \\
\hline $628-8(A-D)$ & $6 / 28 / 94$ & 21 & n.a. & n.a. \\
\hline $628-9(A-D)$ & $6 / 28 / 94$ & 72 & 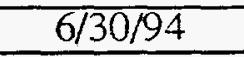 & 43 \\
\hline $628-10(\mathrm{~A}-\mathrm{D})$ & $6 / 28 / 94$ & 9.7 & n.a. & n.a. \\
\hline $630-1(A-D)$ & $6 / 30 / 94$ & 5.7 & n.a. & n.a. \\
\hline $630-2(A-D)$ & $6 / 30 / 94$ & 7.3 & n.a. & n.a. \\
\hline $630-3(A-D)$ & $6 / 30 / 94$ & n.a. (See Note 2) & n.a. & n.a. \\
\hline $630-4(A-D)$ & $6 / 30 / 94$ & 64 & n.a. & n.a. \\
\hline $630-5(A-D)$ & $6 / 30 / 94$ & 38 & n.a. & n.a. \\
\hline $\begin{array}{c}630-6(\mathrm{~A}-\mathrm{D}) \\
\text { Retest of } 628-9 \\
\end{array}$ & $6 / 30 / 94$ & $\overline{43}$ & n.a. & n.a. \\
\hline $705-1(\mathrm{~A}-\mathrm{D})$ & $7 / 5 / 94$ & 120 & $7 / 12 / 94$ & 61 \\
\hline $705-2(A-D)$ & $7 / 5 / 94$ & 120 & $7 / 12 / 94$ & 56 \\
\hline $705-3(A-D)$ & $7 / 5 / 94$ & ND & n.a. & n.a. \\
\hline $705-4(A-D)$ & $7 / 5 / 94$ & 130 & $7 / 12 / 94$ & 49 \\
\hline $705-5(A-D)$ & $7 / 5 / 94$ & 120 & $7 / 12 / 94$ & 46 \\
\hline $\begin{array}{c}712-1(\mathrm{~A}-\mathrm{D}) \\
\text { Retest of } 705-5\end{array}$ & $7 / 12 / 94$ & 46 & n.a. & n.a. \\
\hline $\begin{array}{c}712-2(\mathrm{~A}-\mathrm{D}) \\
\text { Retest of } 705-2 \\
\end{array}$ & $7 / 12 / 94$ & 56 & n.a. & n.a. \\
\hline $\begin{array}{c}712-3(\mathrm{~A}-\mathrm{D}) \\
\text { Retest of } 705-1 \\
\end{array}$ & $7 / 12 / 94$ & 61 & n.a. & n.a. \\
\hline $712-4(A-D)$ & $7 / 12 / 94$ & 190 & $8 / 4 / 94$ & 14 \\
\hline $712-5(A-D)$ & $7 / 12 / 94$ & 200 & $7 / 21 / 94$ & $\overline{8.3}$ \\
\hline $712-6(A-D)$ & $7 / 12 / 94$ & 230 & $7 / 21 / 94$ & 17 \\
\hline
\end{tabular}




\begin{tabular}{|c|c|c|c|c|}
\hline $\begin{array}{c}712-7(\mathrm{~A}-\mathrm{D}) \\
\text { Retest of } 705-4\end{array}$ & $7 / 12 / 94$ & 49 & n.a. & n.a. \\
\hline $721-1(A-D)$ & $7 / 21 / 94$ & 11 & n.a. & n.a. \\
\hline $\begin{array}{c}721-2(A-D) \\
\text { Retest of } 712-6\end{array}$ & $7 / 21 / 94$ & 17. & n.a. & n.a. \\
\hline $721-3(\mathrm{~A}-\mathrm{D})$ & $7 / 21 / 94$ & 10 & n.a. & n.a. \\
\hline $\begin{array}{c}721-4(\mathrm{~A}-\mathrm{D}) \\
\text { Retest of } 712-5\end{array}$ & $7 / 21 / 94$ & 8.3 & n.a. & n.a. \\
\hline $721-5(A-D)$ & $7 / 21 / 94$ & 32 & n.a. & n.a. \\
\hline $721-6(A-D)$ & $7 / 21 / 94$ & 11 & n.a. & n.a. \\
\hline $\begin{array}{c}\text { System Final } \\
\text { Water } \\
\text { (See Note 3) }\end{array}$ & $8 / 3 / 94$ & $\overline{\mathrm{ND}}$ & n.a. & n.a. \\
\hline $804-1(\mathrm{~A}-\mathrm{D})$ & $8 / 4 / 94$ & 25 & n.a. & n.a. \\
\hline $804-2(A-D)$ & $8 / 4 / 94$ & 12 & n.a. & n.a. \\
\hline $804-3(\mathrm{~A}-\mathrm{D})$ & $8 / 4 / 94$ & 27 & n.a. & n.a. \\
\hline $804-4(A-D)$ & $8 / 4 / 94$ & 26 & n.a. & n.a. \\
\hline $804-5(A-D)$ & $8 / 4 / 94$ & 16 & n.a. & n.a. \\
\hline $804-6(A-D)$ & $8 / 4 / 94$ & 22 & n.a. & n.a. \\
\hline $804-7(\mathrm{~A}-\mathrm{D})$ & $8 / 4 / 94$ & 27 & n.a. & n.a. \\
\hline $804-8(A-D)$ & $8 / 4 / 94$ & 110 & $8 / 10 / 94$ & $\mathrm{ND}$ \\
\hline $804-9(\mathrm{~A}-\mathrm{D})$ & $8 / 4 / 94$ & 15 & n.a. & n.a. \\
\hline $\begin{array}{c}804-10(\mathrm{~A}-\mathrm{D}) \\
\text { Retest of } 712-4\end{array}$ & $8 / 4 / 94$ & 14 & n.a. & n.a. \\
\hline $804-11(\mathrm{~A}-\mathrm{D})$ & $8 / 4 / 94$ & 45 & n.a. & n.a. \\
\hline $\begin{array}{l}\text { 804-12(A-D) } \\
\text { (See Note 4) }\end{array}$ & $8 / 4 / 94$ & $\begin{array}{c}310 \\
\text { (See Note 4) } \\
\end{array}$ & n.a. & n.a. \\
\hline $\begin{array}{l}810-1(\mathrm{~A}-\mathrm{E}) \\
\text { (See Note 5) }\end{array}$ & $8 / 10 / 94$ & ND & n.a. & n.a. \\
\hline
\end{tabular}

TTLC - Total Threshold Limit Concentration

STLC - Soluble Threshold Limit Concentration

$\mathrm{ND}$ - Compound not present at or above the detection limit ( $1 \mathrm{ppm}$ for solids, $50 \mathrm{ppb}$ for water).

n.a. - Not applicable.

Note 1 - Sample of fine solids ( $<100 \mathrm{uM})$ fraction only.

Note 2 - Sample from original dirty stockpile prior to treatment, not reported.

Note 3 - Sample of final system water after all soil washing was completed.

Note 4 - Untreated dry soil from under soil washer.

Note 5 - 810-1(A-E) is a composite from a 59 c.y. remediation pile which includes the material sampled in 804-8 and 804-12. 


\section{Source of Further Information}

Robert J. Cena

Lawrence Livermore National Laboratory

7000 East Avenue

Livermore, CA 94550

(510) $422-7336$

David W. Bieber, R. G. or

Kenneth Crabtree

Genesis Eco Systems Incorporated

3341 Fitzgerald Road, Suite D

Rancho Cordova, California 95742

(916) 638-5733 